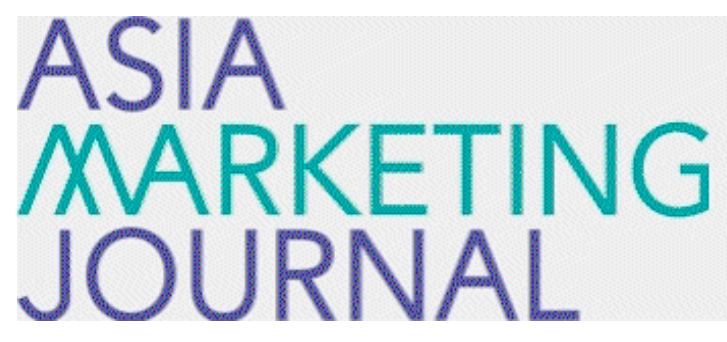

ASIA MARKETING JOURNAL

Volume 17 | Issue 3

Article 3

10-31-2015

\title{
Exploratory Study of the Impact of Social Media Marketing on Consumer Purchase Intention
}

Tayyaba Noreen

Sang-Lin Han

Follow this and additional works at: https://amj.kma.re.kr/journal

Part of the Marketing Commons

\section{Recommended Citation}

Noreen, Tayyaba and Han, Sang-Lin (2015) "Exploratory Study of the Impact of Social Media Marketing on Consumer Purchase Intention," Asia Marketing Journal: Vol. 17 : Iss. 3 , Article 3.

Available at: https://doi.org/10.15830/amj.2015.17.3.53

This Article is brought to you for free and open access by Asia Marketing Journal. It has been accepted for inclusion in Asia Marketing Journal by an authorized editor of Asia Marketing Journal. 


\title{
Exploratory Study of the Impact of Social Media Marketing on Consumer Purchase Intention: Comparative Study of Pakistan and South Korea
}

\author{
Tayyaba Noreen* \\ Sang-Lin Han**
}

\begin{abstract}
Social media marketing have drawn substantial attention in business and academia. This study examines the impact of social media marketing on purchase intention of consumer in South Korea and Pakistan. The research background rests on literature of social media, social media marketing, electronic word of mouth and social media advertisement. Descriptive research method is adopted for the purpose of this study. The findings indicated that South Korean users have higher intention to purchase products through social media platforms as compared to users in Pakistan. The results also show that electronic word of mouth has greater influence on purchase intention as compared to advertisement on social networks. Managerial implications and limitations of the study results were also discussed.
\end{abstract}

Key words: Social media marketing, SMM, Electronic word of mouth, eWOM, Social media advertisement, Purchase intention

\section{Introduction}

Social media marketing is a new field of marketing. As the name states, it is the advertising products or services on social media networks. However, it also implies marketing through the social media networks. Today SMM has become an emerging research area. Research into social media, is still at an embryonic stage, and interest is focused mostly on a B2C context (Michaelidou, Siamagka, \& Christodoulides, 2011). The Internet as marketplace is a subject extensively debated by researchers and practi-

\footnotetext{
* Professor of the University of Balochistan, Quetta, Pakistan, Doctoral Candidate of Hanyang University (Tayyabaarshad40@yahoo.com)

** Professor of Marketing Hanyang University Business School (slhan@hanyang.ac.kr), Corresponding Author
} 
tioners for more than ten years but limited research attention has been paid so far to marketing issues related to what is widely seen as the new stage of the Internet evolution (Constantinides, 2009).

Now the companies and retailers are using social media networks not only for the promotion of their products but also for selling the product and getting the customers feedback. Social Media is empowering people to become the new influencers, and it is forcing PR and marketing professionals to recognize and include these powerful tools in their advertising and marketing communications strategies (Solis \& Breakenridge, 2009). Social networking sites provide people with the tools and opportunity to be part of international communities that share opinions and content and communicate directly with one another or to other large communities (Kelly, Kerr, \& Drennan, 2010). Social media, especially social networking sites, provide a virtual space for people to communicate through the Internet, which also might be an important agent of consumer socialization (Vinerean, Cetina, Dumitrescu, \& Tichindelean, 2013).

Organizations and businesses are just beginning to recognize and utilize the power of Web 2.0 social media (Thackeray, Neiger, Hanson, \& McKenzie, 2008). Promotions are particularly effective as they add excitement to online purchasing and an incentive for customers to invite other friends (Saravanakumar \& SuganthaLakshmi, 2012). Marketing activity using social media platforms entertains customers by offering a variety of free contents as well as social network activity, and enables customized information searching. Activities on the brand's social media platforms create interaction among users that can lead to word-of mouth effects and include fashion and trend attributes(Kim \& Ko, 2012). social media have transformed the Internet from a platform for information, to a platform for influence (Hanna, Rohm, \& Crittenden, 2011). (Zhou, 2014) Social media, as the "new new media" with numerous advanced forms, is becoming more popular globally. Firms, organizations and governments can employ this "new new media" to market themselves.

This research is an effort to estimate the frequency of consumer purchase intention through social media marketing in two different populations. This study wishes to determine the impact of social media marketing on purchase intention of Korean consumers as well as Pakistani consumers. The main objective of this research study was to make a descriptive survey that assesses the influence of social media on consumer purchase intention based on relevant literature and theories. Next objective of the study is to investigate consumer response to the impact of electronic word of mouth on their behavior. This study also aims to analyze consumers' response towards advertisement on social media. The specific objective of this study is to investigate cross national variation in two distinct elements of SMM: (1) Advertisement (2) eWOM on purchase intention. 
〈Figure 1〉 Elements of Social Media Marketing(SMM)

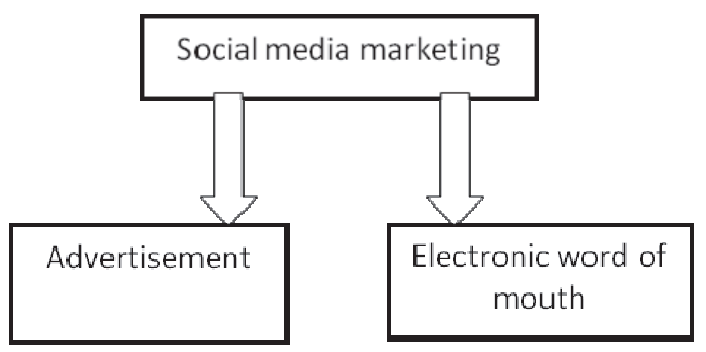

The structure of this article is as follows: firstly, existing literature has been reviewed. Then data collection procedure and instrument has been discussed. The result section is divided into three subsections. First section investigates and compares the influence of online advertisement on Korean and Pakistani respondents. Second section presents the cross national comparison of the findings about the influence of electronic word of mouth. Third sections evaluate the purchase intention of respondents from both countries. Finally conclusion, research limitations and suggestions for future research are discussed.

Contribution of this study is twofold. First, we develop a framework that includes both elements (advertisement and electronic word of mouth) of SMM. Because in previous studies we reviewed we were unable to find any studies which have demonstrated both variables together. Second, we tested the hypotheses in cross national context. Because despite the growing number of cross national studies in different field there is limited growth in the field of social media marketing specifically in the con- text of cross national study(Goodrich, 2014). Little research is available about the function of social media and other online marketing communication tools, particularly regarding their international applicability.

\section{Literature Review}

Researchers and media experts have proposed various definitions for social media. According to techtarget.com social media is the collective of online communication channels for interaction, content sharing, and collaboration. Social media encompasses a wide range of online, word of mouth forums including blogs, company sponsored discussion boards and chat rooms, or service rating websites, internet discussion boards, and social networking websites (Mangold \& Faulds, 2009). Social media introduce substantial and pervasive changes to communication between organizations, communities, and individuals (Kietzmann, Hermkens, McCarthy, \& Silvestre, 2011). O’Brien(2011) mentioned that Social media is a realm where users are very aware of the fact that business and users within their community can access their information and view their actions.

\subsection{Social Media Advertisement}

According to Wikipedia, Social media adver- 
tising is a particular segment of marketing that utilizes internet's social platforms to deliver commercial massages to potential consumers. Online advertisements are portions of a website that are formatted for the purpose of delivering a marketing message that seek to attract customers to purchase a product or service (Mohammed \& Alkubise, 2012). A social ad is an online ad that incorporates user interactions that the consumer has agreed to display and be shared (Tucker, 2012). The rise in social media advertising also marks a continued trend by marketers to establish more intimate relationships with their customers (Wright, Khanfar, Harrington, \& Kizer, 2010). Lester(2012) agrees that the inclusion of social media as a communication media is essential to an advertising curriculum for integrated marketing communication to be complete. Social media provide an ideal advertising medium for green advertisers because consumers can self-select into sustainable lifestyle groups (Minton, Lee, Orth, Kim, \& Kahle, 2012). With the prosperity of social media, marketers attempt to take advantage of social advertising to effectively disseminate advertisements (Li \& Shiu, 2012).

\subsection{Electronic Word of Mouth}

Word-of mouth communication (WOM), the process allows consumers to share information and opinions that direct buyers towards and away from specific products, brands, and serv- ices (Hawkins, Best and Coney 2004). eWOM, is a concept frequently found at the foundations of social media dialogue(Lange-Faria \& Elliot, 2012). social media enabling customers to talk to one another is an extension of traditional word-of-mouth communication (Mangold \& Faulds, 2009).

Jansen et al.(2009) states that through eWOM consumers share their experiences and reactions about any business with other consumers voluntarily. eWoM refer any positive or negative statement made by potential, actual, and former customers about a product or a company via internet. Hennig Thurau et al, (2004). The use of various electronic technologies such as online discussion forum, electronic bulletin board, newsgroups, blogs, social networking sites facilitate the information exchange among communicators(Goldsmith 2006). (Khammash \& Griffiths, 2011) states, negative eWoM can cause costly or even irreparable damage. According to (Bataineh, 2015) eWOM quality is the most influential dimension (predictor) on purchase intention. Word of mouth can influence others' views, thoughts and their decision. If word of mouth power utilized correctly, it could market any product/ services for the long time (Nawaz, Vveinhardt, \& Raheem, 2014). WOM communication strategies are appealing because they combine the prospect of overcoming consumer resistance with significantly lower costs and fast delivery especially through technology such as the Internet (Trusov, Bucklin, \& Pauwels, 2009). Social 
media brings a new dimension to word of mouth marketing as consumers were found to be very trusting of their online community in terms of intent to purchase. Gil-Or(2010) states that the messages that are delivered by word of mouth are usually more credible, as the receiver has the reason to believe that the sender of the message got no benefit for transferring the information.

\subsection{Social Media Marketing}

As literature indicates that social media marketing involve both advertising and viral marketing (electronic word of mouth) efforts via social networking sites. Social media marketing, also known as word-of-mouth marketing, viral marketing, buzz, and guerilla marketing is the intentional influencing of consumer-to-consumer communications by professional marketing techniques (Cvijikj \& Michahelles, 2011). (Chatzithomas, Boutsouki, Chatzithomas, \& Zotos, 2014) states that "Social media represent a hybrid element of the promotional mix. They combine the features of the traditional tools of Integrated Marketing Communications (B2C) and a significant channel of word of mouth communication (C2C) where marketing professionals cannot control the type, the range and the distribution of information".

Social networking sites have become an important arena for marketing. They are a tool for advertisement of products, promotion of brands. According to techtarget.com social media marketing is taking the advantage of social net- working to help a company increase brand exposure and broaden customer reach and goal is to create content compelling enough that user will share it with their social networks. Karl Vance et al.(2008), define Social media marketing carries the advantage of low cost, rapid transmission through a wide community and user interaction. Sisira Neti(2011) defines that SMM consist of the attempt to use social media to persuade consumers that one's company, products or services are worthwhile. Social media marketing is characterized by social connectivity and user interactivity in the brand's attempt to communicate with its consumers and prospects (Chi, 2011).

SMM marketing is using online communities, social networks, blog marketing and more. Social media marketing is primarily internet based but has similarities with non internet based, marketing methods like word of mouth marketing. According to word stream, SMM is a form of internet marketing that implements various social media networks in order to achieve marketing communication and branding goals. Kazim et al,(2011) stated that promoting brands and other marketing activities through social media doesn't cost the firm so much then it is widely evaluated as the most convenient instrument to market products to the target segment. SMM is the way of promoting a website, brand or business by interacting with or attracting the interest of current or prospective customers through the channel of social media. O’Brien(2011) con- 
cluded that the relationship between the consumer and a business has changed significantly as a result of social media. These platforms facilitate the formation of relationships in terms of customer acquisition, but they are more useful and regarded as more appropriate for relationship maintenance as a customer retention platform. According to Bolotaeva(2010), there are opportunities for businesses to grow public awareness and get involved in the communities, as well as continue to research for other ways to advertise on social platforms.

\subsection{Cross national research}

The existing research about cross national study on impact of SMM is very limited(Malhotra, 1996), In recent years cross-cultural marketing research has assumed great importance in the academic and business worlds. Examining the cross-national applicability of consumer behavior constructs and models is becoming increasingly more important (Durvasula, 1993). In their discussion of existing research, Whitelock and his colleagues(2013) state that it is now clear that these social media outlets have become significant promotional vehicles and that there is potential for many firms to use them crossnationally. Bell(2010) state that the World Wide Web has evolved, it has provided new tools that enable such firms to internationalize more rapidly and engage more effectively with customers in a wider range of more complex busi- ness activities. Zhou(2007) states that international business managers should consider social networks as an efficient means of helping internationally oriented SMEs to go international more rapidly and profitably. Netemeyer(1991) found that because of the recent increase in the multinationalization of business, marketers have a growing need for cross-national constructs and measures that are reliable, valid, and applicable across countries. According to Harzing(2006), the globalization of the world economy and the increasing importance of multinational companies have made more and more researchers realize that theories and concepts developed in one part of the world might not be applicable across borders. In order to find out which theories and concepts are universally valid and which have to be adapted, cross-national research is necessary and often this type of research is conducted using surveys.

\section{Methodology}

The methodology chosen to attain the main aim and objectives of this research is based on a cross national survey. According to Malhotra (1996) in a cross country analysis, the data of all the countries are analyzed simultaneously. Descriptive analysis has been used to describe survey statistics. (Pareek, 1975), Survey and interviews are the most widely used methods 
in cross cultural research.

\subsection{Participants}

The population of interest for this study is all social media users in South Korea and Pakistan. A convenience sample of 50\% from both populations was chosen for inclusion in this study. There were 300 participants in final sample for this study. Out of 150 participants, we had 31 drop-out from Korean sample and 16 drop-out from Pakistani sample, making the final sample size of 119 and 134 participants in each national group.

\subsection{Instrument}

For the survey closed ended questionnaire was used to collect the primary data. Survey was comprised of two sections. The first $\mathrm{sec}^{-}$ tion included general information. The second section was designed to understand the impact of social media marketing. Survey contained 25 questions including (1 to 10) demographic questions, and characteristics about factors, advertisement on social media platforms (11 to 16), electronic word of mouth (online reviews and comments) (17 to 20), and purchase intention (21 to 25). All items were measured from using five point Likert scale with the anchors being1 for "strongly agree" to 5 for "strongly disagree". However, all questions of the survey were structured in order to increase the participation. All questions included in the survey were adopted from previous literature.

\subsection{Procedure}

For this study both offline and online survey was conducted for getting the response from participants. Survey was distributed between April-20-2015 to May-20-2015. Survey using questionnaire has been used to collect demographic information and answers of questions about the factors included in this study. Survey forms were distributed among university students, faculty members and other internet users.

\subsection{Research Hypotheses}

To examine the effect of social media advertisement, and electronic word of mouth on users' intention to purchase, we hypothesized:

\subsubsection{Analysis of perception of cross national respondents about social media advertisement}

Hypothesis 1: All cross national respondents will have different perception about social media advertisement.

\subsubsection{Analysis of perception of cross national respondents about electronic word of mouth}


Hypothesis 2: The perception behind electronic word of mouth is similar for both Korea based and Pakistan based respondents.

\subsubsection{Cross national analysis of purchase intention}

Hypothesis 3: Pakistan based and Korea based respondents will have different level of influential value about impact of SMM on their purchase intention.

\subsection{Results and Data Analysis}

For analyzing the data, SPSS was used. After the data collection, the reliability coefficient was measured and the lowest Cronbach's Alpha of measurement variables was 0.81 which was above recommended level 0.70 .

\subsection{Cross National Demographic Analysis}

Demographic information provides a generalized view in terms of gender, age, education, occupation etc. For this study overall sample consisted of 253 responses. 〈Table 1〉 shows the demographic information for complete set of data that was collected from two countries. In this survey, 53\% respondents are from Pakistan while 47\% participants are from South Korea. 〈Table 1〉 shows that sample was made up mostly of male respondents $66 \%$ and $34 \%$ female respondents. Majority of the respondents
(90\%) have post graduate qualification.

Among the respondents (58.10\%) are from the age group of 21 to 30. Followed by (34.39\%) are from age group of 31 to 40. Which implies that majority of respondents is young generation. (87.4\%) respondents are students because the questionnaires were distributed in different universities of both countries. The highest representative of respondents $83 \%$ uses internet more than three hours per day. This may indicate that the respondents are experienced users of social media.

As one of the purpose of this survey is to know the users opinions about social media marketing. 52.96\% of respondents use social networks for searching information while 35.97\% of participants use social media for sharing contents, discussion and for social networks. Almost half of the respondents $49.80 \%$ com- $^{-}$ mented that advertisement on social media has medium influence on their buying decisions. While advertisement on social media platforms has large affect on 33.99\% respondents. 5.53\% respondents were not sure about this statement.

A significant number of respondents $61.27 \%$ commented that electronic word of mouth (online reviews and comments) largely influence their purchase intention. While electronic word of mouth has medium and small influence $27.66 \%$ on respondents. In terms of advertisement method $46.25 \%$ of participants like advertisement on YouTube. 37.94\% of respondents were in favor of Face book and Google advertisement method. 
〈Table 1〉 Demographic

\begin{tabular}{|c|c|c|c|}
\hline Variable & Category & Frequency & Percentage \\
\hline Age & $\begin{array}{l}\text { Under } 20 \\
21-30 \\
31-40 \\
41-50 \\
\text { 0ver50 }\end{array}$ & $\begin{array}{r}0.0 \\
147 \\
87 \\
15 \\
4\end{array}$ & $\begin{array}{r}0.00 \\
58.10 \\
34.39 \\
5.93 \\
1.58\end{array}$ \\
\hline Gender & $\begin{array}{l}\text { Male } \\
\text { Female }\end{array}$ & $\begin{array}{r}167 \\
86\end{array}$ & $\begin{array}{l}66.0 \\
34.0\end{array}$ \\
\hline Nationality & $\begin{array}{l}\text { Pakistan } \\
\text { South Korea }\end{array}$ & $\begin{array}{l}134 \\
119 \\
\end{array}$ & $\begin{array}{l}53.0 \\
47.0 \\
\end{array}$ \\
\hline Education & $\begin{array}{l}\text { Secondary School } \\
\text { Under graduate } \\
\text { Post graduate } \\
\text { Doctoral }\end{array}$ & $\begin{array}{r}0.0 \\
22 \\
227 \\
4 \\
\end{array}$ & $\begin{array}{r}0.00 \\
8.7 \\
89.7 \\
1.6 \\
\end{array}$ \\
\hline Occupation & $\begin{array}{l}\text { Student } \\
\text { Academics } \\
\text { Employee } \\
\text { Businessmen } \\
\text { Other }\end{array}$ & $\begin{array}{r}221 \\
19 \\
7 \\
4 \\
2\end{array}$ & $\begin{array}{r}87.4 \\
7.5 \\
2.8 \\
1.6 \\
.8\end{array}$ \\
\hline Use frequency & $\begin{array}{l}\text { Less than } 1 \text { hour } \\
1-<2 \text { hour } \\
2-<3 \text { hour } \\
3+\end{array}$ & $\begin{array}{r}0.0 \\
11 \\
32 \\
210\end{array}$ & $\begin{array}{r}0.00 \\
4.35 \\
12.65 \\
83.00\end{array}$ \\
\hline Reason of engagement & $\begin{array}{l}\text { Sharing contents } \\
\text { Social Network } \\
\text { Videos and Contents } \\
\text { Discussion } \\
\text { Searching Information } \\
\text { Social games }\end{array}$ & $\begin{array}{r}23 \\
46 \\
17 \\
22 \\
134 \\
11\end{array}$ & $\begin{array}{r}9.09 \\
18.18 \\
6.71 \\
8.70 \\
52.96 \\
4.35 \\
\end{array}$ \\
\hline Influence of advertisement & $\begin{array}{l}\text { Large } \\
\text { Medium } \\
\text { Small } \\
\text { Not Sure }\end{array}$ & $\begin{array}{r}86 \\
126 \\
26 \\
14\end{array}$ & $\begin{array}{r}33.99 \\
49.80 \\
10.28 \\
5.53\end{array}$ \\
\hline Influence of eWOM & $\begin{array}{l}\text { Large } \\
\text { Medium } \\
\text { Small } \\
\text { Not Sure }\end{array}$ & $\begin{array}{r}155 \\
43 \\
27 \\
28\end{array}$ & $\begin{array}{l}61.27 \\
16.99 \\
10.67 \\
11.07 \\
\end{array}$ \\
\hline Advertisement method & $\begin{array}{l}\text { Google advertising } \\
\text { Face book } \\
\text { You Tube } \\
\text { Twitter } \\
\text { Banner Advert } \\
\text { Mobile } \\
\text { Other }\end{array}$ & $\begin{array}{r}42 \\
54 \\
117 \\
4 \\
6 \\
30 \\
0\end{array}$ & $\begin{array}{r}16.60 \\
21.34 \\
46.25 \\
1.58 \\
2.37 \\
11.86 \\
0.00\end{array}$ \\
\hline
\end{tabular}




\section{Social Media Marketing Analysis}

Second part of the analysis consists of three subsections. First section 〈Table 2〉 investigates six statements which were related to the advertisement on social networks. Next section 〈Table 3〉 investigates consumer reaction towards online review and comments. It consists of 4 statements. The last section of 〈Table 4$\rangle$ consists of 5 statements that investigate consumer intention to purchase through social networks. First column of 〈Table 2, 3, 4〉 explain statements of survey. Next columns represents likert scale, frequency, percentage of responses, mean, standard deviation, and rank. All values except rank are derived from survey responses. The values which were presented in the rank column are derived from mean values.

\subsection{Cross- National Analysis of Social Media Advertisement}

One purpose of survey is to know the users opinion about advertisement on social media platforms and its impact on their purchase decisions. Descriptive data analysis about advertisement on social media platforms 〈Table 2〉 shows that $41.2 \%$ Korean participants disagree and fully disagree with the statement that choosing products through social media platforms is a wise idea while $33.6 \%$ are not sure about this issue. $25.2 \%$ participants are in favor of this statement. In contrast $45.5 \%$ of participants from Pakistan disagree and strongly disagree that choosing product through social media advertisement is a wise idea. Therefore, 25.4\% respondents are agreed and fully agreed with this statement. 29.1\% Pakistani respondents are not sure about this statement. With regard to the statement about social media advertisement there is a similarity in responses of respondents from two countries. As this is the bottom ranked statement of this section with mean value 1.66 and 1.73 in Korea and Pakistan respectively. $83.2 \%$ of Korean respondents were agreed and fully agreed that those advertisement increases interest in products and services. While only $6.7 \%$ of respondents were in disagreement and full disagreement about this issue. In contrast, $81.3 \%$ of Pakistani respondents were agreed and fully agreed and $9.7 \%$ were in disagreement and full disagreement with this statement.

Most interesting findings of the survey were on the issue related to the enjoyment of advertisement on social media platforms $72.3 \%$ of Korean respondents and $18.7 \%$ of Pakistani respondents were agreed and fully agreed that such advertisements are relevant with their personal interest and they enjoy these advertisements. 33.6\% Pakistani respondents were not sure about this statement. The rate of respondents from Korea who were disagree and fully disagree is $14.3 \%$ while $47.8 \%$ Pakistani respondents think that these advertisements are not relevant to 
〈Table 2〉 Statements of respondents about social media advertisement

\begin{tabular}{|c|c|c|c|c|c|c|c|c|c|c|c|}
\hline Statement & & outh & Korea & & $=119$ & & & Pakis & & $\mathrm{n}=1$ & \\
\hline \multirow{6}{*}{$\begin{array}{l}\text { I feel choosing products } \\
\text { and a service to buy } \\
\text { through advertisement } \\
\text { on social media platform } \\
\text { is wise idea. }\end{array}$} & Scale & $\mathrm{F}$ & $\%$ & mean & $\mathrm{SD}$ & Rank & $\mathrm{F}$ & $\%$ & mean & $\mathrm{SD}$ & Rank \\
\hline & $\begin{array}{l}\text { Strongly } \\
\text { Agree }\end{array}$ & 9 & 7.6 & \multirow{5}{*}{3.17} & \multirow{5}{*}{1.060} & \multirow{5}{*}{2} & 10 & 7.5 & \multirow{5}{*}{3.24} & \multirow{5}{*}{1.105} & \multirow{5}{*}{4} \\
\hline & Agree & 21 & 17.6 & & & & 24 & 17.9 & & & \\
\hline & Not sure & 40 & 33.6 & & & & 39 & 29.1 & & & \\
\hline & \begin{tabular}{|l|} 
Disagree \\
\end{tabular} & 39 & 32.8 & & & & 46 & 34.3 & & & \\
\hline & \begin{tabular}{|l|} 
Strongly \\
Disagree
\end{tabular} & 10 & 8.4 & & & & 15 & 11.2 & & & \\
\hline \multirow{5}{*}{$\begin{array}{l}\text { Advertisement on social } \\
\text { media platforms } \\
\text { increases my interest in } \\
\text { buying products and } \\
\text { services. }\end{array}$} & $\begin{array}{l}\text { Strongly } \\
\text { Agree }\end{array}$ & 72 & 60.5 & \multirow{5}{*}{1.66} & \multirow{5}{*}{.995} & \multirow{5}{*}{6} & 78 & 58.2 & \multirow{5}{*}{1.73} & \multirow{5}{*}{1.070} & \multirow{5}{*}{6} \\
\hline & Agree & 27 & 22.7 & & & & 31 & 23.1 & & & \\
\hline & Not sure & 12 & 10.1 & & & & 12 & 9.0 & & & \\
\hline & Disagree & 5 & 4.2 & & & & 9 & 6.7 & & & \\
\hline & $\begin{array}{l}\text { Strongly } \\
\text { Disagree }\end{array}$ & 3 & 2.5 & & & & 4 & 3.0 & & & \\
\hline \multirow{5}{*}{$\begin{array}{l}\text { The ads that appear on } \\
\text { my profile are relevant } \\
\text { to my personal interests } \\
\text { and I enjoy seeing them. }\end{array}$} & \begin{tabular}{|l|} 
Strongly \\
Agree
\end{tabular} & 42 & 35.3 & \multirow{5}{*}{2.09} & \multirow{5}{*}{1.089} & \multirow{5}{*}{4} & 6 & 4.5 & \multirow{5}{*}{3.34} & \multirow{5}{*}{.989} & \multirow{5}{*}{3} \\
\hline & Agree & 44 & 37.0 & & & & 19 & 14.2 & & & \\
\hline & Not sure & 16 & 13.4 & & & & 45 & 33.6 & & & \\
\hline & Disagree & 14 & 11.8 & & & & 51 & 38.1 & & & \\
\hline & \begin{tabular}{|l|} 
Strongly \\
Disagree
\end{tabular} & 3 & 2.5 & & & & 13 & 9.7 & & & \\
\hline \multirow{5}{*}{$\begin{array}{l}\text { I feel Advertisement on } \\
\text { social media platforms } \\
\text { can influence my buying } \\
\text { decision. }\end{array}$} & $\begin{array}{l}\text { Strongly } \\
\text { Agree }\end{array}$ & 73 & 61.3 & \multirow{5}{*}{1.78} & \multirow{5}{*}{1.208} & \multirow{5}{*}{5} & 51 & 38.1 & \multirow{5}{*}{2.23} & \multirow{5}{*}{1.250} & \\
\hline & Agree & 22 & 18.5 & & & & 34 & 25.4 & & & \\
\hline & Not sure & 7 & 5.9 & & & & 24 & 17.9 & & & 5 \\
\hline & Disagree & 11 & 9.2 & & & & 17 & 12.7 & & & \\
\hline & \begin{tabular}{|l|} 
Strongly \\
Disagree \\
\end{tabular} & 6 & 5.0 & & & & 8 & 6.0 & & & \\
\hline & $\begin{array}{l}\text { Strongly } \\
\text { Agree }\end{array}$ & 32 & 26.9 & & & & 6 & 4.5 & & & \\
\hline I feel seeing an & Agree & 27 & 22.7 & & & & 10 & 7.5 & & & \\
\hline $\begin{array}{l}\text { advertisement on social } \\
\text { media platforms is }\end{array}$ & Not sure & 22 & 18.5 & 2.73 & 1.448 & 3 & 47 & 35.1 & 3.50 & .971 & 1 \\
\hline $\begin{array}{l}\text { media platiorms is } \\
\text { waste of time. }\end{array}$ & \begin{tabular}{|l|} 
Disagree \\
\end{tabular} & 17 & 14.3 & & & & 53 & 39.6 & & & \\
\hline & \begin{tabular}{|l|} 
Strongly \\
Disagree \\
\end{tabular} & 21 & 17.6 & & & & 18 & 13.4 & & & \\
\hline I feel advertisement on & $\begin{array}{l}\text { Strongly } \\
\text { Agree }\end{array}$ & 4 & 3.4 & & & & 4 & 3.0 & & & \\
\hline social media platforms & Agree & 13 & 10.9 & & & & 14 & 10.4 & & & \\
\hline have greater influence & Not sure & 45 & 37.8 & 3.43 & .962 & 1 & 52 & 38.8 & 3.46 & .963 & 2 \\
\hline as compared to reviews & Disagree & 42 & 35.3 & & & & 45 & 33.6 & & & \\
\hline and comments of users & \begin{tabular}{|l|} 
Strongly \\
Disagree \\
\end{tabular} & 15 & 12.6 & & & & 19 & 14.2 & & & \\
\hline
\end{tabular}


their personal interest and they do not enjoy seeing them. With regard to the importance of advertisement on social media, $79.8 \%$ of re- $^{-}$ spondents from Korea were agreed and fully agreed that these advertisements can influence their buying decision. On the other hand, 63.5\% Pakistani respondents were in agreement and full agreement with this statement. The rate of responses from Korea and Pakistan who were in disagreement and fully disagreement were $14.2 \%$ and $18.7 \%$ respectively.

The top ranked statement in Pakistan with mean value 3.50 was about disadvantage of advertisement on social networks, 53\% of $\mathrm{re}^{-}$ spondents from Pakistan were disagreed and fully disagreed that such advertisement is a waste of time, while $49.6 \%$ of Korean respondents were agreed and fully agreed with this statement. $31.9 \%$ of Korean respondents disagree and fully disagree that seeing advertisement on social networks is waste of time.

Last statement of this section is top ranked statement with mean value 3.43 in Korea is related with the impact of social media advertisement, $47.9 \%$ of Korean respondents and $47.8 \%$ of respondents from Pakistan were disagree and fully disagree that advertisement on social networks has greater influence as compared to online reviews and comments. Response rate of both samples is quite similar about this issue as $14.3 \%$ and $13.4 \%$ of respondents were in favor of advertisement. However, majority of the items have different ranking for both sam- ples which prove that H1 is accepted.

\subsection{Cross-National Analysis of Electronic Word of Mouth}

Next part of analysis was related to attitude of respondents towards online reviews and comments about products and services. According to the results shown in $\langle$ Table 3$\rangle, 50.4 \%$ of respondents from Korea and $50 \%$ of respondents from Pakistan were agreed and fully agreed that online reviews and comments increases their interest in products and services. Interestingly, $23.5 \%$ and $27.6 \%$ of respondents were disagreed and fully disagreed with this statement in both samples.

$52.9 \%$ of Korean participants agreed and fully agreed that online reviews and comments can influence their buying decisions. In contrast, 46.3\% of Pakistani participants agreed and fully agreed with this statement. On the other hand $21.9 \%$ and $23.8 \%$ of respondents from Korea and Pakistan were disagreed and fully disagreed about the influence of online reviews and comments on their buying decisions. However, 25.2\% and $29.9 \%$ respondents were not sure about the influence of electronic word of mouth on their buying behavior. For the issue about reading online reviews and comments is an enjoyment with mean value for both samples is 3.44 and 3.53, $49.6 \%$ of Korean respondents and 54.5\% of respondents from Pakistan were greed and fully agreed that they enjoy reading these re- 
views and comments. While respondents who were not sure about this issue were $25.2 \%$ and 20.1\% from Korea and Pakistan.

Statements regarding influence of online reviews and comments on behavior, rate of $\mathrm{re}^{-}$ sponses, which were agreed and fully agreed that such reviews and comments have greater influence as compared to advertisement, were
51.3\% from Korea and 44.1\% from Pakistan. Mean value of this statement in Korea and Pakistan is 3.50 and 3.32 respectively. $20.2 \%$ of respondents from Korea and $26.9 \%$ of respondents from Pakistan disagreed and fully disagreed with this statement. Results and ranking of all items for both samples proves that the hypothesis was accepted.

〈Table 3〉 Statements of respondents about Electronic Word of Mouth

\begin{tabular}{|c|c|c|c|c|c|c|c|c|c|c|c|}
\hline Statement & & outh & Korea & & $=119$ & & & Pakis & & $\mathrm{n}=1$ & \\
\hline \multirow{6}{*}{$\begin{array}{l}\text { Reviews and comments by } \\
\text { users on social media } \\
\text { platforms increase my } \\
\text { interest in products and } \\
\text { services. }\end{array}$} & Scale & $F$ & $\%$ & mean & $\mathrm{SD}$ & Rank & $F$ & $\%$ & mean & $\mathrm{SD}$ & Rank \\
\hline & \begin{tabular}{|l|} 
Strongly \\
Agree
\end{tabular} & 20 & 16.8 & \multirow{5}{*}{3.59} & \multirow{5}{*}{1.210} & \multirow{5}{*}{1} & 27 & 20.1 & \multirow{5}{*}{3.44} & \multirow{5}{*}{1.318} & \multirow{5}{*}{2} \\
\hline & Agree & 40 & 33.6 & & & & 40 & 29.9 & & & \\
\hline & Not sure & 31 & 26.1 & & & & 30 & 22.4 & & & \\
\hline & Disagree & 26 & 21.8 & & & & 26 & 19.4 & & & \\
\hline & \begin{tabular}{|l|} 
Strongly \\
Disagree
\end{tabular} & 2 & 1.7 & & & & 11 & 8.2 & & & \\
\hline \multirow{5}{*}{$\begin{array}{l}\text { I feel Review and } \\
\text { comments of users on } \\
\text { social media platforms can } \\
\text { influence my buying } \\
\text { decisions. }\end{array}$} & \begin{tabular}{|l|} 
Strongly \\
Agree
\end{tabular} & 30 & 25.2 & \multirow{5}{*}{3.55} & \multirow{5}{*}{1.126} & \multirow{5}{*}{2} & 30 & 22.4 & \multirow{5}{*}{3.41} & \multirow{5}{*}{1.152} & \multirow{5}{*}{3} \\
\hline & Agree & 33 & 27.7 & & & & 32 & 23.9 & & & \\
\hline & Not sure & 30 & 25.2 & & & & 40 & 29.9 & & & \\
\hline & Disagree & 24 & 20.2 & & & & 27 & 20.1 & & & \\
\hline & \begin{tabular}{|l|} 
Strongly \\
Disagree \\
\end{tabular} & 2 & 1.7 & & & & 5 & 3.7 & & & \\
\hline \multirow{5}{*}{$\begin{array}{l}\text { I enjoy reading the } \\
\text { reviews and comments of } \\
\text { users on social networking } \\
\text { sites. }\end{array}$} & \begin{tabular}{|l|} 
Strongly \\
Agree
\end{tabular} & 28 & 23.5 & \multirow{5}{*}{3.44} & \multirow{5}{*}{1.183} & \multirow{5}{*}{4} & 34 & 25.4 & \multirow{5}{*}{3.53} & \multirow{5}{*}{1.249} & \multirow{5}{*}{1} \\
\hline & Agree & 31 & 26.1 & & & & 39 & 29.1 & & & \\
\hline & Not sure & 30 & 25.2 & & & & 27 & 20.1 & & & \\
\hline & \begin{tabular}{|l|} 
Disagree \\
\end{tabular} & 25 & 21.0 & & & & 27 & 20.1 & & & \\
\hline & $\begin{array}{l}\text { Strongly } \\
\text { Disagree } \\
\end{array}$ & 5 & 4.2 & & & & 7 & 5.2 & & & \\
\hline \multirow{5}{*}{$\begin{array}{l}\text { I feel reviews and } \\
\text { comments of users have } \\
\text { greater influence on } \\
\text { behavior as compared to } \\
\text { advertisement on social } \\
\text { media platforms. }\end{array}$} & \begin{tabular}{|l|}
$\begin{array}{l}\text { Strongly } \\
\text { Agree }\end{array}$ \\
\end{tabular} & 29 & 24.4 & \multirow{5}{*}{3.50} & \multirow{5}{*}{1.178} & \multirow{5}{*}{3} & 25 & 18.7 & \multirow{5}{*}{3.32} & \multirow{5}{*}{1.193} & \multirow{5}{*}{4} \\
\hline & Agree & 32 & 26.9 & & & & 34 & 25.4 & & & \\
\hline & \begin{tabular}{|l|} 
Not sure \\
\end{tabular} & 34 & 28.6 & & & & 38 & 28.4 & & & \\
\hline & Disagree & 17 & 14.3 & & & & 28 & 20.9 & & & \\
\hline & \begin{tabular}{|l|} 
Strongly \\
Disagree
\end{tabular} & 7 & 5.9 & & & & 8 & 6.0 & & & \\
\hline
\end{tabular}




\subsection{Cross-National Analysis of Consumer Purchase Intention}

The focus of this survey was purchase in- tention of users hence it was necessary to analyze the responses of participants. With regard to the importance of social media marketing, $32.8 \%$ participants from Korea and $34.3 \%$ re-

$\langle$ Table 4〉 Statements of respondents about Purchase Intention

\begin{tabular}{|c|c|c|c|c|c|c|c|c|c|c|c|}
\hline Statement & \multicolumn{3}{|c|}{ South Korea } & \multicolumn{2}{|c|}{$\mathrm{n}=119$} & & \multicolumn{3}{|c|}{ Pakistan } & \multicolumn{2}{|c|}{$\mathrm{n}=134$} \\
\hline \multirow{6}{*}{$\begin{array}{l}\text { Using social media platforms } \\
\text { help me make decisions } \\
\text { better before purchasing } \\
\text { goods and services. }\end{array}$} & Scale & $\mathrm{F}$ & $\%$ & mean & SD & Rank & $\mathrm{F}$ & $\%$ & mean & S.D & Rank \\
\hline & $\begin{array}{l}\text { Strongly } \\
\text { Agree }\end{array}$ & 9 & 7.6 & \multirow{5}{*}{2.87} & \multirow{5}{*}{.996} & \multirow{5}{*}{2} & 18 & 13.4 & \multirow{5}{*}{2.99} & \multirow{5}{*}{1.217} & \multirow{5}{*}{2} \\
\hline & Agree & 30 & 25.2 & & & & 28 & 20.9 & & & \\
\hline & Not sure & 57 & 47.9 & & & & 42 & 31.3 & & & \\
\hline & Disagree & 13 & 10.9 & & & & 29 & 21.6 & & & \\
\hline & $\begin{array}{l}\text { Strongly } \\
\text { Disagree } \\
\end{array}$ & 10 & 8.4 & & & & 17 & 12.7 & & & \\
\hline & $\begin{array}{l}\text { Strongly } \\
\text { Agree }\end{array}$ & 10 & 8.4 & & & & 12 & 9.0 & & & \\
\hline 1 have high intention to use & Agree & 44 & 37.0 & & & & 29 & 21.6 & & & \\
\hline social media platforms for & Not sure & 49 & 41.2 & 2.62 & .883 & 4 & 61 & 45.5 & 2.88 & .958 & 3 \\
\hline products and services. & Disagree & 13 & 10.9 & & & & 27 & 20.1 & & & \\
\hline & $\begin{array}{l}\text { Strongly } \\
\text { Disagree } \\
\end{array}$ & 3 & 2.5 & & & & 5 & 3.7 & & & \\
\hline & $\begin{array}{l}\text { Strongly } \\
\text { Agree }\end{array}$ & 10 & 8.4 & & & & 13 & 9.7 & & & \\
\hline I have high intention to buy & Agree & 33 & 27.7 & & & & 33 & 24.6 & & & \\
\hline products through social & Not sure & 47 & 39.5 & 2.83 & .968 & 3 & 57 & 42.5 & 2.81 & .951 & 4 \\
\hline media platforms. & Disagree & 25 & 21.0 & & & & 28 & 20.9 & & & \\
\hline & $\begin{array}{l}\text { Strongly } \\
\text { Disagree } \\
\end{array}$ & 4 & 3.4 & & & & 3 & 2.2 & & & \\
\hline & $\begin{array}{l}\text { Strongly } \\
\text { Agree }\end{array}$ & 2 & 1.7 & & & & 2 & 1.5 & & & \\
\hline I will strongly recommend & Agree & 15 & 12.6 & & & & 23 & 17.2 & & & \\
\hline $\begin{array}{l}\text { using social media platforms } \\
\text { for searching information }\end{array}$ & Not sure & 39 & 32.8 & 3.50 & .938 & 1 & 62 & 46.3 & 3.22 & .862 & 1 \\
\hline about products. & Disagree & 47 & 39.5 & & & & 38 & 28.4 & & & \\
\hline & $\begin{array}{l}\text { Strongly } \\
\text { Disagree }\end{array}$ & 16 & 13.4 & & & & 9 & 6.7 & & & \\
\hline & $\begin{array}{l}\text { Strongly } \\
\text { Agree }\end{array}$ & 69 & 58.0 & & & & 69 & 51.5 & & & \\
\hline I plan to buy products & Agree & 36 & 30.3 & & & & 41 & 30.6 & & & \\
\hline $\begin{array}{l}\text { through soclal medla } \\
\text { platforms within three }\end{array}$ & Not sure & 7 & 5.9 & 1.61 & .903 & 5 & 12 & 9.0 & 1.79 & 1.055 & 5 \\
\hline $\begin{array}{l}\text { platforms witnin tnree } \\
\text { months. }\end{array}$ & Disagree & 5 & 4.2 & & & & 7 & 5.2 & & & \\
\hline & $\begin{array}{l}\text { Strongly } \\
\text { Disagree }\end{array}$ & 2 & 1.7 & & & & 5 & 3.7 & & & \\
\hline
\end{tabular}


spondents from Pakistan agree and fully agree that social media platforms are helpful when deciding to make a purchase. In contrast, 19.3\%, and $34.3 \%$ respondents were in disagreement and full disagreement with the importance of social media marketing. On the issue of searching information about products and services through social media networks, $45.4 \%$ and $30.6 \%$ of respondents from Korea and Pakistan were agreed and fully agreed that they have high intention to use social media platforms for searching information. This implies that Korean respondents are more willing to adopt social media marketing then Pakistani respondents. On the other hand $13.4 \%$ and $23.8 \%$ respondents in both samples were disagreed and fully disagreed that they have high intention to use social media platforms. However, a large percentage $41.2 \%$ and $45.5 \%$ of respondents were not sure about their intention.

$36.1 \%$ of respondents in Korea were agreed and fully agreed that they have high intention to buy products through social media platforms. On the other hand $24.4 \%$ respondents disagreed and fully disagreed with statement about high intention to purchase. As compared to Korean sample, 34.3\% of respondents from Pakistan were agreed and fully agreed that their purchase intention is very high. However, $39.5 \%$ and $42.5 \%$ of respondents were not sure about their purchase intention in both samples.

With regard to the statement about users' intention, $14.3 \%$ and $18.7 \%$ of respondents agreed and fully agreed that they will recommend the use of social media networks to others for searching information about products and services. 52.9\% and $35.1 \%$ respondents in both samples were in disagreement and full disagreement about recommending the use of social media platforms. This statement was top ranked in both samples with mean value 3.50 in Korea and 3.22 in Pakistan.

88.3\% of Korean respondents have planned to purchase products through social media platform with in next three months. While $82.1 \%$ of respondents from Pakistan agreed and fully agreed that they will buy products within next three months. On the other hand 5.9\% and 9.0\% respondents in both samples were not sure about their plan in to purchase in near future. The rate of responses in Korea and Pakistan were $5.9 \%$ and $8.9 \%$ who were disagreed and fully disagreed with this statement. Ranking of all items prove that $\mathrm{H} 0$ is accepted.

\section{Conclusion}

This paper empirically contributes to the understanding of consumer behavior across the totally different cultures, with a focus on SMM. This study has advanced knowledge by addressing the role of electronic word of mouth and advertisement on social media and its impact on purchase intention. Overall the outcomes came from a survey for which the questionnaire 
was the main instrument used to gather the needed data. Final analysis was done based on the outcomes which came from 119 internet users from South Korea and 134 users from Pakistan. This study compares the results of survey between both samples. Majority of Korean respondents enjoy advertisement on social networks. It was generally concluded that majority of respondents reported that advertisement on social networks increases their interest in products and services. $79.8 \%$ of Korean users and $63.5 \%$ of Pakistani users indicated that social media advertisement can influence their buying decisions. In terms of first research hypothesis, it has been proved that all cross national respondents have different perception about social media advertisement. The study also shows that all items about online reviews and comments are significant. Majority of respondents in both samples believed that online reviews and comments can influence their buying decisions and they enjoy reading online reviews and comments. However ranking of items is different for both samples which prove that the perception behind electronic word of mouth is different for both Korea based and Pakistan based respondents. At the essence, it was concluded that majority of participants who took part in our survey believed that they will buy products through social media platforms in near future; however, they have negative opinion about recommending the use of social networks to others for searching information about products and services.
It is to be noted that research hypothesis proved that Pakistan based and Korea based respondents have similar level of influential value about impact of SMM on their purchase intention.

\subsection{Managerial implications}

This research observed the willingness of consumers for buying products through social media marketing. The findings of this research have certain managerial implications for marketers. This study has implications for marketing communication, positioning strategies and multinational marketing strategies.

The study will help the policy makers regarding making policy related to manufacturing and marketing of consumer products not only in domestic market but also in international markets. Marketing process through social networks can be made more effective by utilizing the results of this research.

As the study highlights the significance of advertisement on social networks and electronic word of mouth for purchase intention, the marketers can make new customers by understanding the likes and dislikes of consumers. The results clearly show that consumers in different countries have different opinion about electronic word of mouth and advertisement on social networks; these are accredited to difference in social, economic, and cultural values. As Goodrich(2014) mentioned that little is known about the best way for marketers to use social media. Even 
less is known about international differences in consumer usage of social media and how eWOM influences consumer decision-making

This study develop understanding of SMM across nations which suggest to the marketers should pay attention to make better policy about advertisement of their products because influence of word of mouth is higher as compared to advertisement.

This study is first of its kind highlighting both elements (advertisement and electronic word of mouth) of social media marketing, hence the study portray better picture of SMM and its impact on consumer behavior. The study asserts the need for managers to understand the importance of both elements when managing marketing through social media.

\subsection{Limitations and future research}

Although this research has achieved its objectives but still it has certain limitations. First of all, due to the limited time this research has compared purchase intention of consumers from two countries. Future research should include more developed countries or less developed countries for comparing the consumer intention for buying products through social media platforms.

Second, in this study all respondents are apparently from one city in Korea and one city in Pakistan, therefore the chances of variation can be taken into account if sample is extended to other large cities.
Another limitation of this study is related to the sample size. This study was conducted on small sample size from both populations; therefore it will be interesting to determine whether these findings hold in more diverse and large samples.

Questionnaire design is another limitation of this study because it is possible that items for measuring the purchase intention may not included enough information for measuring consumer's actual behavior. Hence for future research more items should be considered for measuring consumer's purchase intention.

Despite the fact that the nature of this study is exploratory, this research is able to provide new insights by applying more advanced analytical model; limitation about research methodology still exists. Considering this limitation it is recommended that new analytical model such as structural equation modeling can be applied in future.

〈Received September 15. 2015〉

〈Revised October 25. 2015〉

〈Accepted October 29. 2015〉

\section{References}

Bataineh, A. Q. (2015). The Impact of Perceived e-WOM on purchase intention: The mediating role of corporate image. International Journal of Marketing Studies, 7(1), p126. 
Bell, J., \& Loane, S. (2010). 'New-wave' global firms: Web 2.0 and SME internationalisation. Journal of Marketing Management, 26 (3-4), 213-229.

Bolotaeva, V., \& Cata, T. (2010). Marketing opportunities with social networks. Journal of Internet Social Networking and Virtual Communities, 2010, 1-8.

Chatzithomas, N., Boutsouki, N., Chatzithomas, L., \& Zotos, Y. (2014). Social media advertising platforms: a cross-cultural study. International Journal of Strategic Innovative Marketing, 1(2).

Chi, H.-H. (2011). Interactive digital advertising vs. virtual brand community: Exploratory study of user motivation and social media marketing responses in Taiwan. Journal of Interactive Advertising, 12(1), 44-61.

Constantinides, E. (2009). Social Media/Web 2.0 as marketing parameter: An introduction. Paper presented at the Proceedings of 8th international congress marketing trends.

Cvijikj, I. P., \& Michahelles, F. (2011). Understanding social media marketing: a case study on topics, categories and sentiment on a Facebook brand page. Paper presented at the Proceedings of the 15th International Academic MindTrek Conference: Envisioning Future Media Environments.

Gil-Or, O. (2010). Building consumer demand by using viral marketing tactics within an online social network. Advances in Management, 3(7), 7-14.
Durvasula, S., Andrews, J. C., Lysonski, S., \& Netemeyer, R. G. (1993). Assessing the cross-national applicability of consumer behavior models: A model of attitude toward advertising in general. Journal of Consumer Research, 626-636.

Goldsmith, R.E. (2006), Electronic Word-ofMouth.

Goodrich, K., \& de Mooij, M. (2014). How 'social' are social media? A cross-cultural comparison of online and offline purchase decision influences. Journal of Marketing Communications, 20(1-2), 103-116.

Harzing, A.-W. (2006). Response Styles in Cross-national Survey Research A 26-country Study. International Journal of Cross Cultural Management, 6(2), 243-266.

Hennig. T, Kevin P, (2004). Electronic word of mouth via consumer-opinion: platforms what motivate consumers to articulate themselves on the internet? Journal of interactive marketing, volume 18.

Hanna, R., Rohm, A., \& Crittenden, V. L. (2011). We're all connected: The power of the social media ecosystem. Business horizons, 54(3), 265-273.

Hawkins, D.I., Best, R. and Coney, K.A. (2004) Consumer Behavior: Building Marketing Strategy, 9th ed. Boston: McGraw Hill. Jansen Bernard J., Zhang Mimi, Sobel Kate, Chowdury Abdur (2009). Twitter Power: Tweets as Electronic Word of Mouth. Journal of American Society for Information 
Science and Technology. 60:11, pp.21692188

Kelly, L., Kerr, G., \& Drennan, J. (2010). Avoidance of advertising in social networking sites: The teenage perspective. Journal of Interactive Advertising, 10(2), 16-27.

Khammash, M., \& Griffiths, G. H. (2011). 'Arrivederci CIAO, com, Buongiorno Bing. com'-Electronic word-of-mouth (eWOM), antecedences and consequences. International Journal of Information Management, 31 (1), 82-87.

Kaplan \& Haenlein 2009 Users of the world, unite! The challenges and opportunities of Social Media

Kazım Kirtiş, Filiz Karahan (2011)To Be or Not to Be in Social Media Arena as the Most Cost-Efficient Marketing Strategy after the Global Recession

Karl V, William. H, Robert. P. Dellavalle, (2008) Social Internet Sites as a Source of Public Health Information.

Kietzmann, J. H., Hermkens, K., McCarthy, I. P., \& Silvestre, B. S. (2011). Social media? Get serious! Understanding the functional building blocks of social media. Business horizons, 54(3), 241-251.

Kim, A. J., \& Ko, E. (2012). Do social media marketing activities enhance customer equity? An empirical study of luxury fashion brand. Journal of Business Research, 65(10), 14801486.

Lange-Faria, W., \& Elliot, S. (2012). Under- standing the role of social media in destination marketing. Tourismos. An International Multidisciplinary Journal of Tourism, 7(1).

Lester, D. H. (2012). Social Media: Changing Advertising Education Prof. Dr. Deborah H. Lester, Kennesaw State University-USA. Li, Y.-M., \& Shiu, Y.-L. (2012). A diffusion mechanism for social advertising over microblogs. Decision support systems, 54(1), 9-22.

Malhotra, N. K., Agarwal, J., \& Peterson, M. (1996). Methodological issues in cross-cultural marketing research: A state-of-the-art review. International marketing review, 13 (5), 7-43.

Mangold, W. G., \& Faulds, D. J. (2009). Social media: The new hybrid element of the promotion mix. Business horizons, 52(4), 357-365.

Michaelidou, N., Siamagka, N. T., \& Christodoulides, G. (2011). Usage, barriers and measurement of social media marketing: An exploratory investigation of small and medium B2B brands. Industrial Marketing Management, 40(7), 1153-1159.

Minton, E., Lee, C., Orth, U., Kim, C.-H., \& Kahle, L. (2012). Sustainable marketing and social media: A cross-country analysis of motives for sustainable behaviors. Journal of Advertising, 41(4), 69-84.

Nawaz, A., Vveinhardt, J., \& Raheem, A. R. (2014). Impact of Word of Mouth on Con- 
sumer Buying Decision. European journal of business and management, 6(31).

Netemeyer, R. G., Durvasula, S., \& Lichtenstein, D. R. (1991). A cross-national assessment of the reliability and validity of the CETSCALE. Journal of marketing research, 320-327.

O’Brien, C. (2011). The emergence of the social media empowered consumer. Irish marketing review, 21(1/2), 32-40.

Saravanakumar, M., \& SuganthaLakshmi, T. (2012). Social media marketing. Life Science Journal, 9(4), 4444-4451.

Sisira Neti, (2011). Social media and its role in marketing. International Journal of Enterprise Computing and Business Systems. Vol. 1 Issue 2

Solis, B., \& Breakenridge, D. K. (2009). Putting the public back in public relations: How social media is reinventing the aging business of PR: FT Press.

Thackeray, R., Neiger, B. L., Hanson, C. L., \& McKenzie, J. F. (2008). Enhancing promotional strategies within social marketing programs: use of Web 2.0 social media. Health promotion practice, 9(4), 338-343.
Trusov, M., Bucklin, R. E., \& Pauwels, K. (2009). Effects of word-of-mouth versus traditional marketing: findings from an internet social networking site. Journal of marketing, 73(5), 90-102.

Tucker, C. (2012). Social advertising. Available at SSRN 1975897.

Vinerean, S., Cetina, I., Dumitrescu, L., \& Tichindelean, M. (2013). The effects of social media marketing on online consumer behavior. International Journal of Business and Management, 8(14), p66.

Whitelock, J., Cadogan, J. W., Okazaki, S., \& Taylor, C. R. (2013). Social media and international advertising: theoretical challenges and future directions. International marketing review, 30(1), 56-71.

Wright, E., Khanfar, N. M., Harrington, C., \& Kizer, L. E. (2010). The lasting effects of social media trends on advertising. Journal of Business \& Economics Research (JBER), 8(11).

Zhou, L., Wu, W.-p., \& Luo, X. (2007). Internationalization and the performance of born-global SMEs: the mediating role of social networks. Journal of International Business Studies, 38(4), 673-690. 